\title{
Thermal Evolution of the Sea Ice in the Taman Bay and the Dinskoy Gulf
}

\author{
A. E. Bukatov, D. D. Zavyalov*, T. A. Solomakha \\ Marine Hydrophysical Institute, Russian Academy of Sciences, Sevastopol, Russian Federation \\ *e-mail: zavyalov.dd@mhi-ras.ru
}

\begin{abstract}
Seasonal evolution of the ice cover thermodynamic processes in the Taman Bay and the Dinskoy Gulf in winter, 2007-2008 is studied based on the one-dimensional thermodynamic sea ice model adapted to the physical and geographical conditions of the Kerch Strait. Model approximation of the thermodynamic processes in the ice-sea system permits to predict thickness and dates of formation, melting and complete destruction of sea ice in the bays. Dependence of regional variability of the ice thickness upon the hydrometeorological factors is analyzed. It is shown that, depending on the type of the atmospheric processes, the sea ice thickness in the Taman Bay can grow both zonally - from the west to the east (intensive ice growth is observed in the first and the second decades of January) and meridionally - from the south to the north (the repeated ice formation in the first and the second decades of February). In case of ultra-polar intrusion of cold air masses, the ice cover over the entire water area of the bay is formed in course of about 2-3 days. During the melting period the decrease of sea ice thickness can reach $4 \mathrm{~cm} /$ day. Seawater salinity change conditioned by the growth of the sea ice thickness is quite noticeable in shallow-water regions of the Dinskoy Gulf, along the eastern coast of the Chushka Spit and also in the northern and northeastern edges of the Taman Bay.
\end{abstract}

Keywords: Taman Bay, Dinskoy Gulf, thermodynamics of sea ice, ice thickness distribution.

DOI: 10.22449/1573-160X-2017-5-19-30

(C) 2017, A. E. Bukatov, D. D. Zavyalov*, T. A. Solomakha

(C) 2017, Physical Oceanography

\section{Introduction}

The Kerch Strait connecting the Black Sea and the Sea of Azov is bounded by Taman Peninsula shores from the east. Tuzla and Chushka Spits separate shallow Dinskoy Gulf and Taman Bay from the Kerch Strait. Complex hydrologic regime of the Kerch Strait and reduced water exchange of gulfs with the sea formed unique local ecosystems which significantly differ from the ones of the Sea of Azov and the Black Sea. A protected natural area, the Taman-Zaporozhye strict nature reserve, covers not only the coasts of Dinskoy Gulf and Taman Bay but also their water area. Ice cover is an important element in the formation of gulf water area hydrologic regime which determines a state of its surface. An advection of ice from the gulfs affects the formation of ice conditions in the Kerch Strait southern part. A paramount role in ice formation belongs to atmospheric processes, their seasonal and interannual features. Contrasting weather conditions in winter period caused by short-time and abrupt changes of air masses have a strong impact on the ice regime. Cold snaps in the sea region greatly worsens ice situation in a relatively short time. For instance, 2005-2006, 2007-2008, 2011-2012 winter seasons were mild for the Sea of Azov and the Kerch Strait water area but according to ice regime criteria (concentration of ice fields, thickness, ice shapes, ridging) they had obvious signs typical for severe type winters. The mentioned seasons were characterized by both intensive ice formation caused by abrupt air temperature decrease and rapid sea clearance from ice related to significant thaws. The work [1] 
is devoted to the analysis of connection of general atmosphere circulation above the northern hemisphere with pronounced cooling at the Sea of Azov.

Numerical models of the thermal dynamics of Arctic seas ice cover are represented in [2,3]. On the basis of the known correlations of ocean and atmosphere heat and dynamic interrelation in [4, 5], an analysis of thermal and radiation balances affecting the Sea of Azov ice cover thickness variation was carried out. In the present work a model of ice cover thickness thermal evolution adapted to physical-geographical and climatic features of the Taman Bay is represented. Model approximation of thermodynamic processes in Ice - Sea system allows one to predict thickness, dates of the formation beginning, melting and total destruction of sea ice in the gulf. Seasonal spatio-temporal variability of sea ice (which forms in the Taman Bay and the Dinskoy Gulf) thickness distribution in winter period 2007-2008 is reproduced.

\section{Ice thermodynamic model}

The thermodynamics of sea ice (formation, growth and ice melting) is described by locally one-dimensional models $[2,6]$. The fast ice is a homogeneous plate and heat propagation in which is described by the heat conduction equation

$$
\rho_{\mathrm{i}} c_{\mathrm{i}} \frac{\partial T_{\mathrm{i}}(z, t)}{\partial t}=\frac{\partial}{\partial z}\left(k_{\mathrm{i}} \frac{\partial T_{\mathrm{i}}(z, t)}{\partial z}\right)-\frac{\partial I(z, t)}{\partial z}, z \in\left[0, h_{\mathrm{i}}(t)\right] .
$$

Here $t$ is a time; $z$ is a vertical coordinate, $z$ axis is directed down from the ice cover upper surface ( $z=0) ; T_{\mathrm{i}}, \rho_{\mathrm{i}}, c_{\mathrm{i}}, k_{\mathrm{i}}, h_{\mathrm{i}}$ are temperature, density, specific heat, thermal conductivity and ice thickness, respectively; $I$ is penetrating solar radiation uniformly distributed over the entire ice thickness. Specific heat and thermal conductivity of ice, as well as the functions of its temperature $T_{\mathrm{i}}(\mathrm{K})$ and salinity $S_{\mathrm{i}}(\%)$, in the range of temperatures $T_{\mathrm{i}}>268.15 \mathrm{~K}$ are taken as

$$
\begin{gathered}
c_{\mathrm{i}}\left(T_{\mathrm{i}}, S_{\mathrm{i}}\right)=c_{\mathrm{i} 0}+\frac{\mu L_{\mathrm{i} 0} S_{\mathrm{i}}}{\left(T_{\mathrm{i}}-273.15\right)^{2}}, \\
k_{\mathrm{i}}\left(T_{\mathrm{i}}, S_{\mathrm{i}}\right)=k_{\mathrm{i} 0}+\frac{\beta S_{\mathrm{i}}}{T_{\mathrm{i}}-273.15} .
\end{gathered}
$$

The symbols $c_{\mathrm{i} 0}, L_{\mathrm{i} 0}, k_{\mathrm{i} 0}$ in formulas $(2,3)$ denote specific heat, latent heat of fusion and thermal conductivity of fresh ice at $0{ }^{\circ} \mathrm{C} ; \mu, \beta$ are empirical coefficients. As the data on brine content in the thin ice of mid-latitude seas are practically absent, then in the range from the ice freezing temperature $T_{\mathrm{f}}$ to $268.15 \mathrm{~K}\left(-5^{\circ} \mathrm{C}\right)$ (characterized by an increased content of the liquid phase) thermophysical variables are considered to be tuned and bounded from above by values at a specified temperature for fresh ice. The freezing point of water with $S_{w}$ salinity is determined by the Krummel formula

$$
T_{\mathrm{f}}=-\left(3 \cdot 10^{-3}+5.27 \cdot 10^{-2} S_{\mathrm{w}}+4 \cdot 10^{-5} S_{\mathrm{w}}^{2}+4 \cdot 10^{-7} S_{\mathrm{w}}^{3}\right),
$$

and ice dencity - by the Weinberg formula

$$
\rho_{\mathrm{i}}\left(T_{1}\right)=917 \cdot\left(1-1.58 \cdot 10^{-4} T_{1}\right)(1-n), n=5.25 \cdot 10^{-4} T_{\mathrm{a}}-2.35 \cdot 10^{-2} .
$$


Here $T_{\mathrm{l}}$ is a temperature which is average between the one of upper ice surface $T_{\text {sfi }}$ and water freezing temperature $T_{\mathrm{f}}$.

Heat fluxes involved in vertical heat exchange between the atmosphere and the underlying surface (water, ice) determine the thermal processes of ice cover thickness variation. At its upper boundary $F_{\mathrm{t}}$ heat flux consists of the incoming short-wave solar radiation $F$ (a part of which is reflected into the atmosphere), $R$ long-wave radiation flux, $F_{\mathrm{s}}$ sensible and $F_{1}$ latent heat. It is assumed that all the energy getting on the underlying surface from the atmosphere (minus the reflected and absorbed short-wave radiation) is spent on surface temperature and ice mass variation. The rate of ice thermal evolution (melting or growing) depends on the difference between $F_{\mathrm{t}}$ heat flux coming from the atmosphere through the upper boundary of the ice cover and $F_{\mathrm{b}}$ heat flux from the water to the ice lower boundary.

Boundary conditions for the equation (1) at the upper $(z=0)$ and lower $(z=$ $\left.=h_{\mathrm{i}}(t)\right)$ surfaces of ice cover express the conditions for the thermodynamic equilibrium

$$
\begin{aligned}
& -k_{\mathrm{i}} \frac{\partial T_{\mathrm{i}}}{\partial \mathrm{z}}=F_{\mathrm{t}}\left(T_{\mathrm{sfi}}\right), z=0, \\
& -k_{\mathrm{i}} \frac{\partial T_{\mathrm{i}}}{\partial \mathrm{z}}=F_{\mathrm{b}}\left(T_{\mathrm{f}}, T_{\mathrm{w}}\right), z=h_{\mathrm{i}}(t) .
\end{aligned}
$$

Using the heat balance equation (4) and assuming that the temperature profile in the ice layer can be described by a linear function, we obtain a nonlinear equation to determine the temperature of the upper ice surface

$$
F_{\mathrm{c}}\left(T_{\mathrm{sf}}, T_{\mathrm{f}}\right)-F_{\mathrm{t}}\left(T_{\mathrm{sf}}\right)=0, z=0,
$$

where $F_{\mathrm{c}}\left(T_{\mathrm{sf} \mathrm{i}}, T_{\mathrm{f}}\right)=k_{\mathrm{i}} \frac{T_{\mathrm{f}}-T_{\mathrm{sf} \mathrm{i}}}{h_{\mathrm{i}}}, \mathrm{z}=0$ is a heat flux through the ice cover.

If $T_{\text {sfi }}$ temperature found at the surface is greater than $T_{\mathrm{mi}}$ ice melting one, we assume that $T_{\mathrm{sfi}}=T_{\mathrm{mi}}$. At the interface between the substance different phases the law of energy conservation during phase transitions is implemented

$$
-\rho_{\mathrm{i}}\left(L_{\mathrm{f}}\right)_{\mathrm{i}} \frac{\partial h_{\mathrm{i}}}{\partial t}=F_{\mathrm{t}}\left(T_{\mathrm{mi}}\right)+k_{\mathrm{i}} \frac{\partial T_{\mathrm{i}}}{\partial \mathrm{z}}, \mathrm{z}=0 .
$$

Temperature and latent heat of fusion of sea ice are taken as equal to $T_{\mathrm{mi}}=-0.054 S_{\mathrm{i}}$ and $L_{\mathrm{fi}}=335 \mathrm{~kJ} / \mathrm{kg}$, respectively. Expression (5) determines the intensity of ice melting at its upper boundary. If the ice cover is absent, then heating or cooling of water mixed layer occurs. Water temperature variation is determined by the following formula

$$
\frac{\partial T_{\mathrm{w}}}{\partial t} \rho_{\mathrm{w}} c_{\mathrm{w}} h_{\mathrm{w}}=F_{\mathrm{b}}-F_{\mathrm{t}},
$$

where $T_{\mathrm{w}}, h_{\mathrm{w}}$ are the temperature and depth of water. $\rho_{\mathrm{w}}$ sea water density is calculated by the empirical equation of state 


$$
\rho_{\mathrm{w}}=1+0.001\left(0.82 S_{\mathrm{w}}+0.0689 T_{\mathrm{w}}-0.0039 S_{\mathrm{w}} T_{\mathrm{w}}-0.00918 T_{\mathrm{w}}{ }^{2}\right),
$$

and $c_{\mathrm{w}}$ specific heat $(\mathrm{kJ} /(\mathrm{kg} \mathrm{K}))$ - by the Mamayev formula

$$
c_{\mathrm{w}}=\left(4.1784+8.46 \cdot 10^{-6}\left(T_{\mathrm{w}}-33.67\right)^{2}-5.075 \cdot 10^{-3} S_{\mathrm{w}}-1.4 \cdot 10^{-5} S_{\mathrm{w}}{ }^{2}\right) \text {. }
$$

Ice thermal evolution rate at the lower boundary is found from the conditions

$$
\begin{gathered}
-\rho_{\mathrm{i}}\left(L_{\mathrm{f}}\right)_{\mathrm{i}} \frac{\partial h_{\mathrm{i}}}{\partial t}=F_{\mathrm{b}}\left(T_{\mathrm{f}}, T_{\mathrm{w}}\right)-k_{\mathrm{i}} \frac{\partial T_{\mathrm{i}}}{\partial z}, z=h_{\mathrm{i}}(t), \\
T_{\mathrm{i}}=T_{\mathrm{f}}, z=h_{\mathrm{i}}(t) .
\end{gathered}
$$

Initial water temperature and salinity are considered to be specified:

$$
T_{\mathrm{w}}(\mathrm{z}, 0)=T_{\mathrm{w} 0}, \quad S_{\mathrm{w}}(\mathrm{z}, 0)=S_{\mathrm{w} 0} .
$$

Turbulent fluxes of sensible and latent heat are calculated by integral aerodynamic formulas [7]

$$
\begin{aligned}
& F_{\mathrm{s}}=C_{\mathrm{pa}} \rho_{\mathrm{a}} \mathrm{StV}_{\mathrm{a}}\left(T_{\overline{\mathrm{sf}} \mathrm{i}}-T_{\mathrm{a}}\right), \quad F_{1}=L \rho_{\mathrm{a}} \operatorname{Da} V_{\mathrm{a}}\left(q_{0}\left(T_{\mathrm{sfi}}\right)-q_{\mathrm{a}}\left(T_{\mathrm{a}}\right)\right), \\
& q_{0}=\left(0.622 e_{0} / p_{\mathrm{a}}\right) 10^{a_{1} T_{\mathrm{sf}} /\left(b_{1}+T_{\mathrm{sfi}}\right)}, \quad q_{\mathrm{a}}=\left(0.622 f / p_{\mathrm{a}}\right) 10^{a_{1} T_{\mathrm{a}} /\left(b_{1}+T_{\mathrm{a}}\right)},
\end{aligned}
$$

$q_{\mathrm{a}}, e, T_{\mathrm{a}}, p_{\mathrm{a}}$ and $V_{\mathrm{a}}$ are specific humidity, water vapor tension, air temperature, atmospheric pressure and wind velocity, respectively; $e_{0}$ is a pressure of saturated water vapor at $0{ }^{\circ} \mathrm{C} ; c_{\mathrm{pa}}$ is heat capacity of air at a constant pressure; $q_{0}$ is a specific humidity of ice cover upper boundary; $f$ is a relative humidity; St, Da are Stanton and Dalton numbers; $L$ is a specific heat of sublimation; $a_{1}, b_{1}$ are empirical coefficients.

For determining $R$ long-wave and $F$ shortwave radiation balances the following formulas [7] are used

$$
\begin{gathered}
R=4 \varepsilon \sigma T_{\text {sfi }} T_{\mathrm{a}}^{3}-\varepsilon \sigma T_{\mathrm{a}}^{4}\left(3.765+0.22 N^{3}\right), \\
F=F_{0}(1-c N)(1-\alpha)\left(1-i_{0}\right), \\
F_{0}=\frac{S \cos ^{2} z_{\Theta}}{\left(\cos z_{\Theta}+2.7\right) e \cdot 10^{-5}+1.085 \cos z_{\Theta}+0.1},
\end{gathered}
$$

where $\sigma$ is the Stefan-Boltzmann constant; $N$ is total cloud amount; $\varepsilon$ is the emissivity of the surface; $F_{0}$ is an incoming short-wave solar radiation for a cloudless sky; $c$ is an empirical coefficient; $\alpha$ is albedo of underlying surface; $i_{0}$ is a coefficient determining what part of short-wave radiation penetrates into the ice and uniformly distributes all over the ice cover; $S$ is the solar constant; $z_{\Theta}$ is a solar zenith angle.

Albedo parameterization is taken from CCSM2 sea ice block of the climate model of the National Research Center (Boulder, Colorado, USA) [8].

Heat flux from the water to the lower ice surface is calculated by the formula

$$
F_{\mathrm{b}}=C_{\mathrm{w}} \rho_{\mathrm{w}} C_{\mathrm{tb}}\left(T_{\mathrm{w}}-T_{\mathrm{f}}\right),
$$

where $C_{\mathrm{tb}}$ is turbulent exchange coefficient. 
As a result of ice formation, an increase of $\Delta S_{\mathrm{w}}$ salinity of water surface layer which is determined by the expression [9] takes place

$$
\Delta S_{\mathrm{w}}=S_{\mathrm{i}} \Delta h_{\mathrm{i}} /\left(h_{\mathrm{w}}+\Delta h_{\mathrm{i}}\right),
$$

where $\Delta h_{\mathrm{i}}$ is an ice thickness increase over the time interval equal to the model step. Newly-formed ice salinity (average over the thickness) during its growth is calculated by the formula [10]

$$
S_{\mathrm{i}}=S_{\mathrm{w}}\left(0.87 e^{-5 \sqrt{h_{\mathrm{i}}}}+0.13\right) .
$$

\section{Numerical modeling results}

On the basis of the constructed thermodynamic model, numerical experiments have been carried out to reconstruct the evolution of ice cover thickness in the Taman Bay in winter 2007-2008. SKIRON predictive model [11] was used as an external forcing. Meteorological data of near-surface temperature forecasting fields, atmospheric pressure, humidity and wind velocity were transformed from the global atmospheric model format into the predictive numerical model one of the ice cover. Computational domain contained 1566 points and included water areas of the Taman Bay and the Dinskoy Gulf. Time step was equal to $2 \mathrm{~h}$. Numerical realization of thermodynamic model was carried out at the following values: $c_{\mathrm{i} 0}=2.106 \mathrm{~kJ} /(\mathrm{kg} \cdot \mathrm{K}) ; L_{\mathrm{i} 0}=340 \mathrm{~kJ} / \mathrm{kg} ; k_{\mathrm{i} 0}=2.3 \mathrm{~W} /(\mathrm{m} \cdot \mathrm{K}) ; \mu=0.054 ; \beta=$ $=0.1172 \mathrm{~W} /(\mathrm{m} \cdot \% 0) ; \rho_{\mathrm{a}}=1.3 \mathrm{~kg} / \mathrm{m}^{3} ; c_{\mathrm{pa}}==10^{3} \mathrm{~J} /(\mathrm{kg} \cdot \mathrm{K}) ; \mathrm{St}=\mathrm{Da}=1.7 \cdot 10^{-3} ; e_{0}=$ $=611 \mathrm{hPa} ; a_{1}=9.5 ; b_{1}=265.5 \mathrm{~K} ; C_{\mathrm{tb}}==10^{-3} \mathrm{~m}^{2} / \mathrm{s} ; i_{0}=0.3$. Monthly average climatic temperature and water salinity in the Taman Bay [12] were specified as initial conditions in the applied model. Cooling surface temperature (water, ice), as well as the one of subglacial sea water, was subsequently calculated from the heat balance equations.

The points with $45^{\circ} 15^{\prime} \mathrm{N}, 36^{\circ} 49^{\prime} \mathrm{E}, 45^{\circ} 21^{\prime} \mathrm{N}, 36^{\circ} 45^{\prime} \mathrm{E}$ and $45^{\circ} 59^{\prime} \mathrm{N}$, $36^{\circ} 35^{\prime} \mathrm{E}$ coordinates were chosen as some characteristic points belonging to the computational domain. Point 1 is located in relatively deep south-western part of the gulf near the exit to the Kerch Strait, point 2 is situated in the northern part of the Taman Gulf near Dinskoy Gulf entrance and point 3 - near the Taman Bay eastern edge. The results of modeling of ice thickness thermal evolution during the period from January to March 2008 for the selected points are represented in Fig. 1. Daily average values of air temperature (Fig. 2, a) according to SKIRON data, as well as the calculated values of the basin surface temperature (Fig. 2, b), underlying water temperature (Fig. 2, c), ice (Fig. 2, d) and water salinity (Fig. 2, e) are given in Fig. 2 for the same points. In case of the absence of ice, surface temperature is taken to be equal to the one of the water and the salinity of zerothickness ice is considered to be equal to the sea water salinity. Thin solid, dashed and bold solid lines in Fig. 1, 2 characterize the changes in the represented physical quantities for points $1-3$, respectively. As an illustration for ice situation emerging in the bay, in Fig. 3-5 computational maps of ice (formed in the same period) thickness are given. Within the water area isolines determine the ice thickness $(\mathrm{cm})$ and outside it - air temperature $\left({ }^{\circ} \mathrm{C}\right)$ according to SKIRON data. 


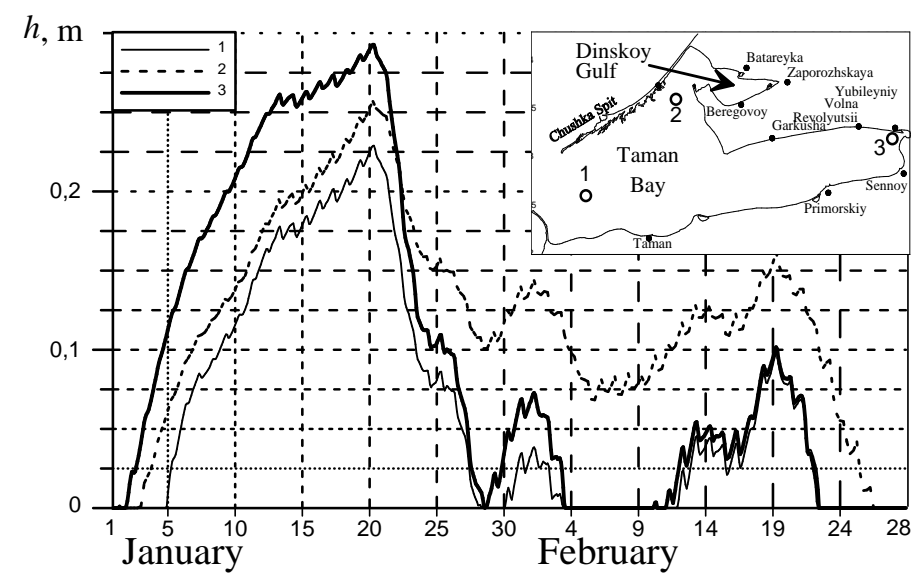

Fig. 1. The results of ice thickness thermodynamic evolution modeling in the selected points of the Taman Bay water area (in point 1 - solid thin line; 2 - dashed line; 3 - solid bold line) over the period from January to March 2008

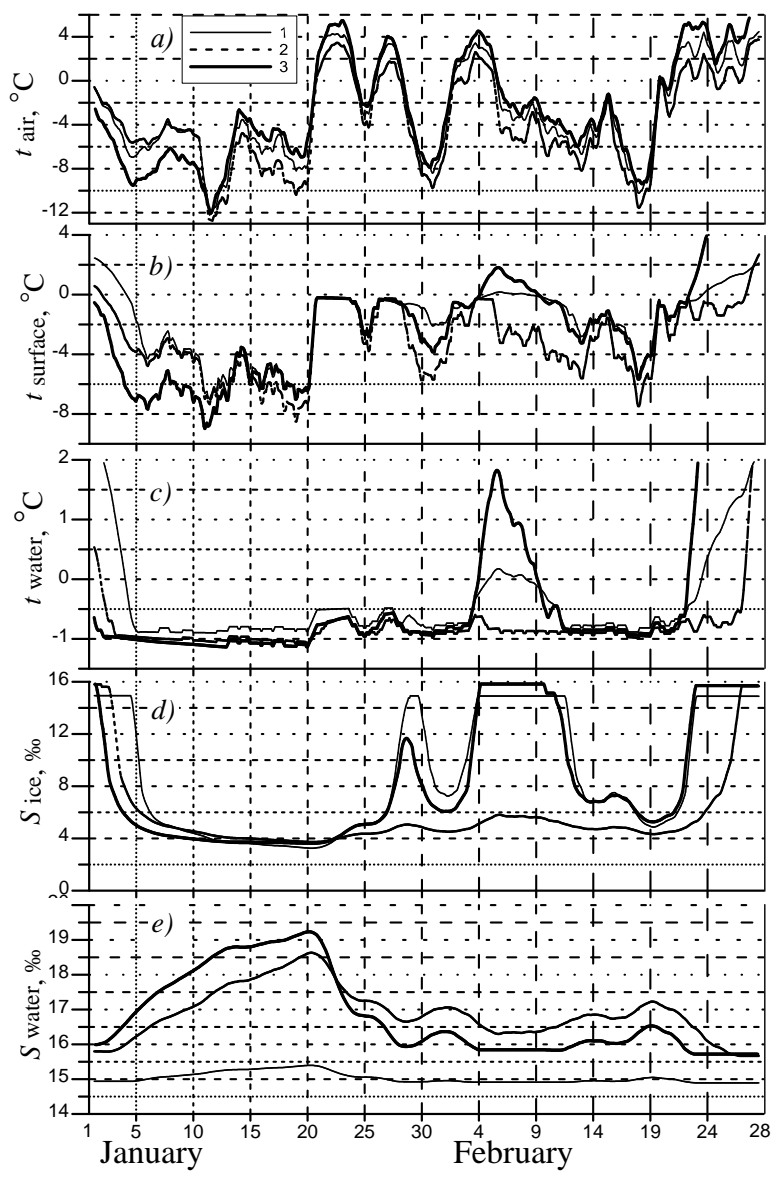

Fig. 2. Daily average air temperature values according to SKIRON data (a) as well as computational values of the basin surface $(b)$, water temperature $(c)$ ice salinity $(d)$ and water salinity for the selected points of the Taman Bay water area 


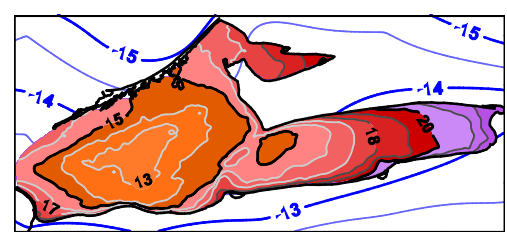

Fig. 3. Computational maps of ice thickness formed from January 3 to 28, 2008

In winter of 2007-2008 ice formation in the Sea of Azov began on November 23 and 26 from the Taganrog Bay and small bays of the sea northern part as a result of cold air intrusion into the rear part of the Atlantic cyclone located above the mid-Volga Region [1, 13]. Subsequent ice accumulation was slow, steady and rather rapid ice formation began only on January 3-4, 2008. At this time in the north of the European part of Russia the Arctic anticyclone which slowly spread to the south was set. According to the numerical modeling results, prerequisites for the formation of ice primary forms in the Taman Bay appeared on January 2 (Fig. 1, 2). Under effect of the settled meteorological situation the ice began to form in shallow areas near the Chushka Spit, in Dinskoy Gulf and in the coastal strip along the northeastern shore between the Rubanov and Markitanskaya Spits (Fig. 3, $a, b$ ). It should be pointed out that air temperature above the southeastern part of the bay was 2-3 degrees lower (Fig. 2, a) than the one above the northeastern part of its basin during the first 10 days of January. The abovementioned fact provided the most intensive ice formation in the southeastern part of the bay. During the period from 3 to 6 January, the in the eastern part of the 
bay ice growth rate was about $5 \mathrm{~cm} /$ day and in the northern part - about $3 \mathrm{~cm} /$ day. During the night from 4 to 5 January ice formation process covered relatively deep eastern and central parts of the bay and by the beginning of the next day their entire water area was covered by the ice of $5-13 \mathrm{~cm}$ thickness (Fig. 3, c).

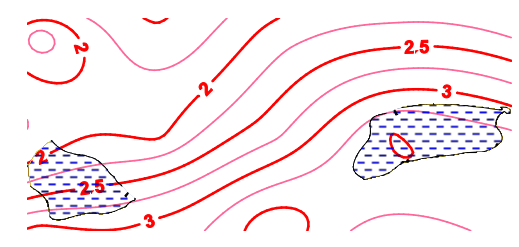

Fig. 4. Computational maps of ice thickness formed from January 22 to February 6, 2008

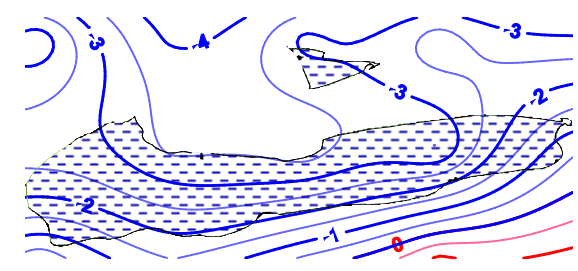

Fig. 5. Computational maps of ice thickness formed from February 11 to 26, 2008 
On January 7-10 the cyclone over the Black Sea was filled, the cold air mass remained above the water area. Air temperature was $8-10^{\circ}$ below zero and it reached its minimum $\left(-15{ }^{\circ} \mathrm{C}\right)$ by the beginning of January 11 . During the period from 7 to 13 January ice cover thickness increased with about $1.8 \mathrm{~cm} /$ day rate making 15-20 cm in the central and up to $25 \mathrm{~cm}$ in the eastern part of the bay at that (Fig. 3, e-h). Further, from January 14 to 19 ice growth slowed down to $1 \mathrm{~cm} /$ day (Fig. 3, i). According to the results of model calculations and to observation data [13], the ice cover in the Taman Bay reached its greatest development on January 20 when the central part of the bay was covered with the ice of 23-25 cm thickness and its eastern part with the one of 25-30 cm thickness (Fig. 3, $j$ ).

During the last 10 days of January - first 10 days of February a short-term warming caused by the anticyclone weakening and passage of deep cyclones which carried warm air from Atlantic and Mediterranean Sea began above the south of the eastern part of Russia. From January 20 to 22 the beginning of ice melting was recorded over the entire water area of the bay (Fig. 1,4). The process of melting started most intensively in the southwest and the east of the bay (about $1 \mathrm{~cm} /$ day), slightly slower (about $0.5 \mathrm{~cm} /$ day) - in the north. Diurnal mean air temperature above the southwestern, western and eastern parts of the bay significantly increased during January 22-23 and made up about 4, 3, $5{ }^{\circ} \mathrm{C}$ as well as daily temperature was about 6,4 and $9{ }^{\circ} \mathrm{C}$, respectively. From January 23 to 27 melting rate in certain areas of the bay reached $4 \mathrm{~cm} /$ day and by January 28 the southwestern and eastern parts of the bay were practically cleared from ice (Fig. 1). The exception was the central and northern parts of the bay where the ice of 5-7 cm thickness (at the southern boundary of the Dinskoy Gulf - up to $10 \mathrm{~cm}$ ) still remained (Fig. 4, c).

In late January - early February weather conditions were unstable when against the background of general warming above the water area of the Sea of Azov a short-time (from January 29 to 31) cold air income with the minimum diurnal temperatures of $6-8{ }^{\circ} \mathrm{C}$ below zero was observed. This caused a repeated ice formation in the open parts of the bay (Fig. 4, d). However, ice formation process was short. The period from February 1 to 10 was characterized by intensive ice melting all over the water area of the bay and almost completed clearance of its part located southward from Rubanovo Cape by the beginning of February 6. Three waves of warm air with the maximum values of temperatures recorded on January 23, 27 and February 4 not only caused an active ice cover melting in the Taman Bay but also provided the warming of the bay waters in those areas which were free from ice. By February 5 in the southwest of the bay open part the water warmed up to $+0.16^{\circ} \mathrm{C}$ and in the east - up to $+1.85^{\circ} \mathrm{C}$ (Fig. 2, c). This largely determined the nature of further thermodynamic processes in the bay related to the subsequent cooling, the last one in this winter season.

From February 11 to 19 an anticyclonic weather type set above the Sea of Azov water area and cold air inflow from the east resumed. This resulted in rather rapid decrease in bay water temperature but, as noted earlier, the water cooling was inhomogeneous. Particularly, warmer southern and eastern parts of the bay cooled slower. In this regard, from February 6 to 11 the position of ice outer edge remained practically unchanged (Fig. 4, f, Fig. 5, a). Only in narrow coastal strips along the eastern shore of Chushka Spit and in the area between Garkusha and 
Volna Revolutsii villages the initial forms of ice with up to $1 \mathrm{~cm}$ thickness were formed. Ice thickness in the ice-covered northern part of the bay increased by about $2 \mathrm{~cm}$. Zonal division of the bay water area by the thickness of the formed ice also remained in future. By February 13 the entire water area of the bay was covered with a solid ice of $2-3 \mathrm{~cm}$ thickness in the south and about $10 \mathrm{~cm}$ in the north (Fig. 5, b). The greatest ice cover development in this period was observed on February 19 when ice thickness near the southern edge of the Dinskoy Gulf reached $15 \mathrm{~cm}$ (Fig. 5, c).

In the beginning of the third part of February cyclonic activity above the Azov - Black Sea region increased. From February 20 to the first days of March an extensive and deep cyclone from the Atlantic with the center above the Baltic Sea covered the entire European part of Russia and changed the temperature background over the Sea of Azov. Active ice cover destruction (Fig. 5, d,e) was observed during this period. The Taman Bay was completely cleared of ice by February 25-26 as evidenced both by the observational data and by the results of model calculations (Fig. 5, f).

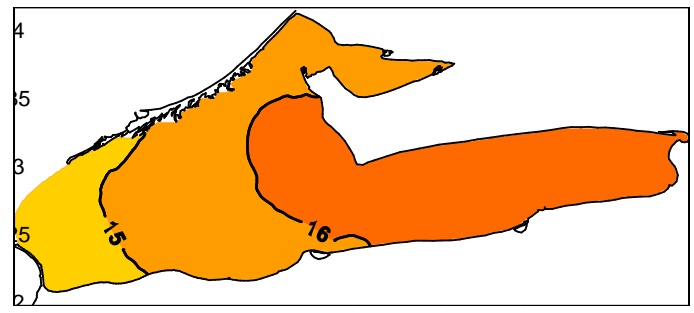

Fig. 6. Mean climatic water salinity distribution for December in the Taman Bay (a) and computational maps of water $(b)$ and ice salinity $(c)$ during the period of the highest ice cover development 
As there are no data on the thermohaline structure of the Taman Bay and Dinskoy Gulf waters during the ice period in an open periodical press, then using the implemented thermodynamic model it seemed interesting to estimate the changes in the salinity of water subglacial layer related to the processes of ice formation. Formation of ice and further increase of its thickness causes precipitation of salts which may significantly change water salinity in the bay. In Fig. 6, $a$ model spatial distribution of open water salinity over the bay water area for the period preceding the ice formation is represented. In Fig. 6, $b, c$ the distributions of subglacial water salinity and ice salinity during the period of the ice cover highest development, respectively, are given. From the figures it is obvious that in relatively deep parts of the bay subglacial water salinity differs little from the one of open water before the ice formation. However, in the sea shallow parts salinity variation can be rather noticeable. Thus, according to calculations, in the Dinskoy Gulf as well as on the eastern shore of the Chushka Spit and in the coastal areas eastwards from Rubanov Cape at ice thickness of about $30 \mathrm{~cm}$ the sea water salinity increased by $20-25 \%$ and reached the values of 19-20\%. Throughout much of the bay water area the salinity made up 3-3.5 \%o and only in the narrow strip near the Chushka Spit and at the eastern edge of the Dinskoy Gulf it reached $4 \%$.

\section{Conclusion}

Thus, the proposed thermodynamic model adapted to the conditions of the Taman Bay and Dinskoy Gulf adequately reproduced the changes in ice thickness at all stages of time on which the ice season 2007-2008 can be conditionally divided. It is shown that depending on the type of atmospheric processes the increase of ice thickness in the Taman Bay can occur both in zonal direction from the west to the east (intensive ice growth during the first 10 days of January - the second ten-day period of January) and in meridional one from the south to the north (repeated ice formation during the first 10 days of February - the second tenday period of February). Model calculations showed that in case of ultra-polar intrusion of cold air masses, the ice cover over the entire water area of the bay is formed in course of about 2-3 days. At the positive ice temperature ice cover destruction is rather active. During the melting period the rate of ice thickness decrease may reach $4 \mathrm{~cm} /$ day value. The change in the salinity of the subglacial water associated with the increase in the ice thickness is quite noticeable in the shallow areas of the Dinskoy Gulf, along the eastern coast of the Chushka Spit and also in the northern and northeastern edges of the bay.

Acknowledgements. The research was carried out within the framework of State Order No. 0827-2015-0001 "Fundamental research of the processes in the ocean - atmosphere - lithosphere system determining spatial-temporal variability of the global and regional scale environment and climate". 


\section{REFERENCES}

1. Fedorenko, A.V., 2009. Osobennosti Ledovogo Sezona 2007-2008 gg. na Azovskom More [Features of the Ice Season 2007-2008 on the Azov Sea]. In: E.S. Nesterov, ed., 2009. Trudy Gidromettsentra Rossii [Proceedings of Hydrometcentre of Russia]. Obninsk: IG-SOTSIN, Iss. 343, Raschety i Prognozy Elementov Rezhima Morya. Dolgosrochnye Meteorologicheskie Prognozy, pp. 79-88. Available at: http://method.meteorf.ru/publ/tr/tr343/tr343.pdf [Accessed: 10 August 2017] (in Russian).

2. Maykut, G.A. and Untersteiner, N., 1971. Some Results from a Time-Dependent Thermodynamic Model of Sea Ice. J. Geophys. Res., [e-journal] 76(6), pp. 1550-1575. doi:10.1029/JC076i006p01550

3. Klyachkin, S.V., Guzenko, R.V. and May, R.I., 2015. Numerical Model of the Ice Cover Evolution in Arctic Seas for the Operational Forecasting. Ice and Snow, [e-journal] 55(3), pp. 83-96. doi:10.15356/2076-6734-2015-3-83-964

4. Bukatov, A.E. and Bukatov, A.A., 2013. Narastanie i Tayanie L'da v Usloviyakh Azovskogo Moray [The Growth and Melting of Ice in the Conditions of the Azov Sea]. In: V.I. Trukhin, Yu.A. Pirogov, K.V. Pokazeev, eds., 2013. Fizicheskie Problemy Ekologii (Ekologicheskaya Fizika). Moscow: MAKS Press, Iss. 19, pp. 108-120. Available at: http://ocean.phys.msu.ru/ecophys/ecophys19_pp3-180.pdf [Accessed: 10 August 2017] (in Russian).

5. Ryabtsev, Y.N., 2014. Modelirovanie Formirovaniya i Tayaniya L'da v Usloviyakh Zimy 2011-2012 gg. dlya Melkovodnykh Rayonov Yuzhnoy Chasti Azovskogo Morya [Modeling the Formation and Melting of Ice in Winter 2011-2012 for Shallow Areas of the Southern Part of the Azov Sea]. In: V.A. Ivanov, ed., 2014. Ekologicheskaya Bezopasnost' Pribrezhnoy $i$ Shel'fovoy Zon Morya [Ecological Safety in Coastal and Shelf Zones of the Sea]. Sevastopol: ECOSI-Gidrofizika, Iss. 28, pp. 356-367 (in Russian).

6. Semtner, A.J., 1976. A Model for the Thermodynamic Growth of Sea Ice in Numerical Investigations of Climate. J. Phys. Oceanogr., [e-journal] 6(3), pp. 379-389. https://doi.org/10.1175/1520-0485(1976)006<0379:AMFTTG>2.0.CO;2

7. Makshtas, A.P., 1984. Teplovoy Balans Arkticheskikh L'dov v Zimniy Period [Thermal Balance of Arctic Ice in Winter]. Leningrad: Gidrometeoizdat, 67 p. (in Russian).

8. Briegleb, B.P., Bitz, C.M., Hunke, E.C., Lipscomb, W.H. and Schramm, J.L., 2002. Description of the Community Climate System Model Version 2: Sea Ice Model. NCAR Technical Report. Boulder, CO: National Center for Atmospheric Research. Available at: http://www.ccsm.ucar.edu/models/ice-csim4 [Accessed: 1 February 2017].

9. Frolov, I., 1981. Chislennaya Model' Osenne-Zimnikh Ledovykh Yavleniy [Numerical Model of Autumn-Winter Ice Phenomena]. In: AARI, 1981. Tr. AANII [Proceedings of Arctic and Antarctic Research Institute], Vol. 372, pp. 73-81 (in Russian).

10. Ryvlin, A.Ya., 1974. Metod Prognozirovaniya Predela Prochnosti Ledyanogo Pokrova na Izgib [Method for Predicting the Ultimate Strength of the Ice Cover for Bending]. Problemy Arktiki i Antarktiki, (45), pp. 79-86 (in Russian).

11. Kallos, G., Nickovic, S., Papadopoulos, A., Jovic, D., Kakaliagou, O., Misirlis, N., Boukas, L., Mimikou, N., Sakellaridis, G., Papageorgiou, J., Anadranistakis, E. and Manousakis, M., 1997. The Regional Weather Forecasting System SKIRON: an Overview. In: Proceedings of the International Symposium on Regional Weather Prediction on Parallel Computer Environments. Athens, 15-17 October 1997. Athens, pp.109-122.

12. Climatic Atlas of the Sea of Azov, 2008. [online] Available at: https://www.nodc.noaa.gov/OC5/AZOV2008/start.html [Accessed: 1 February 2017].

13. Borovskaya, R.V. and Leksikova, L.A., 2008. Features of the Azov Sea Ice Regime in Winter Period, 2007-2008. In: Proceedings of the IV International Symposium on Modern Problems of Ecology of the Azov-Blak Sea Region. Kerch, 8-9 October 2008. Kerch, pp. 30-35. Available at: http://yugniro.ru/files/YugNIRO_Conference_Materials_October-2008.pdf [Accessed: 10 August 2017] (in Russian). 